Raf. J. Sci.,Vol.28, No.2 Special Issue for the Third Scientific Conference of Chemistry, pp.100-111, 2019

\title{
New Tridentate Hydrazone Metal Complexes Derived from 2-Hydroxy-4- Methoxyacetophenone and some Acid Hydrazides: Synthesis, Characterization and Antibacterial Activity Evaluation
}

\author{
Dhufr A. Omer* \\ Abdul Ghany M. Al-Daher \\ Department of Chemistry/ College of Science/ University of Mosul \\ E-mail: dhufr1987@gmail.com*
}

(Received 2/9/2018; Accepted 25/10/2018)

\begin{abstract}
A new series of complexes of $\mathrm{Co}(\mathrm{II}), \mathrm{Ni}(\mathrm{II}), \mathrm{Cu}(\mathrm{II})$, and $\mathrm{Zn}(\mathrm{II})$ with three hydrazones ligands(L) derived from 2-hydroxy-4-methoxy acetophenone (Paeonol) and 4-methylbenzoylhydrazide (AMBH), acetyl hydrazine $(\mathrm{AAH})$, or picolinoyl hydrazine $(\mathrm{APH})$ with the general formula $\left[\mathrm{M}(\mathrm{L}-\mathrm{H})_{2}\right] \cdot \mathrm{nH}_{2} \mathrm{O}$ $(\mathrm{n}=0,1$, or 2$)$ where $\mathrm{L}-\mathrm{H}=$ deprotonated $\mathrm{AMBH}, \mathrm{AAH}$ or $\mathrm{APH}$, have been prepared and characterized by elemental analyses, spectral (FT-IR, UV-visible) as well as molar conductance and magnetic measurements. The data revealed that the ligands AMBH and AAH act as mono-negative ONO chelates coordinated through the carbonyl group and the phenoxy oxygen atoms and azomethine nitrogen atom, while APH acts as NNO chelate, coordinated through the pyridine and azomethine nitrogen atoms and the phenoxy oxygen atom. On the basis of electronic spectral and magnetic moment data, an octahedral geometry is suggested for all complexes. Also, the ligands and some of their complexes were screened for antibacterial activities.
\end{abstract}

Keywords: Hydrazones, Complexes, Transition metals, Antibacterial activity.

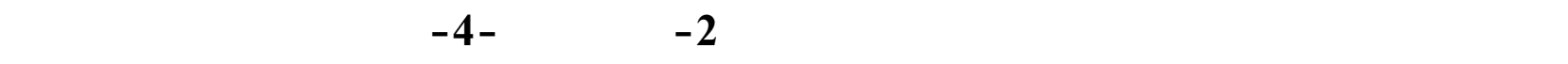

هيرازبدات الحولهض: تحضير وتشخيص وفيم الفعالية المضلاة للبكتيربا

\section{الملغص}

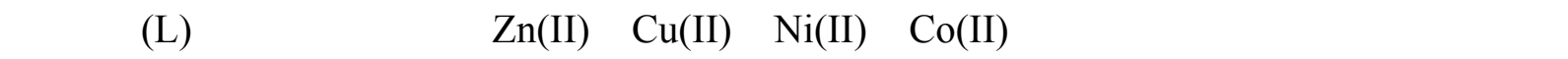
2 -هيدروكسي -4 -ميثوكسي لسيتوفينون (بايونول) وهيدرازيدات الحولمض وهي :2 -هيدروكسي -4 -ميثوكسي السيتوفينون4 -مثيل

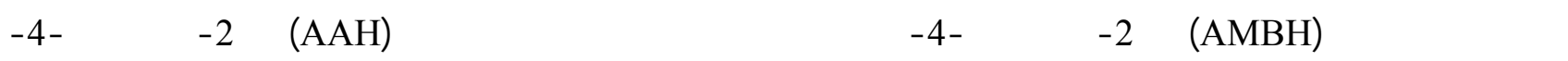
ميثوكسي لسيتوفينون بيكولينويل هيدرازون (APH) ذوات الصيغة العلمة و AAH و APH مذزوعة البروتون.شُخهِت المعقدات المحضرة بولنطة تحاليل العناصر ولطيف الاشعة تحت الحمراء (IR) والطيف الالكترونية (UV-Vis) والقيلست التوصيلية المولارية والحسلسية المغنطيسية وق تحسيد لملوب تنلسق الليكاندات والترلكيب المتوقعة اعتمادَ على البيانت الطيفة والمغنلطيسية. أوضحت هذه البيانت ان الليكاندات

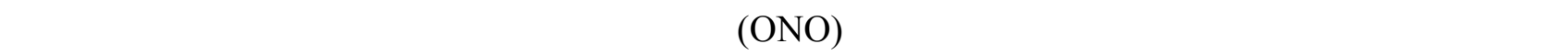

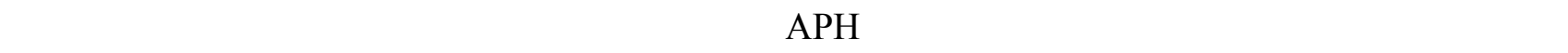
نوع (NNO) ومن خلل ذرة نتروجين مجموعة الايزوميثن والبريين وذرة اوكسجين الفينوكسي. اعتمادا على القيلست الطيفيه 


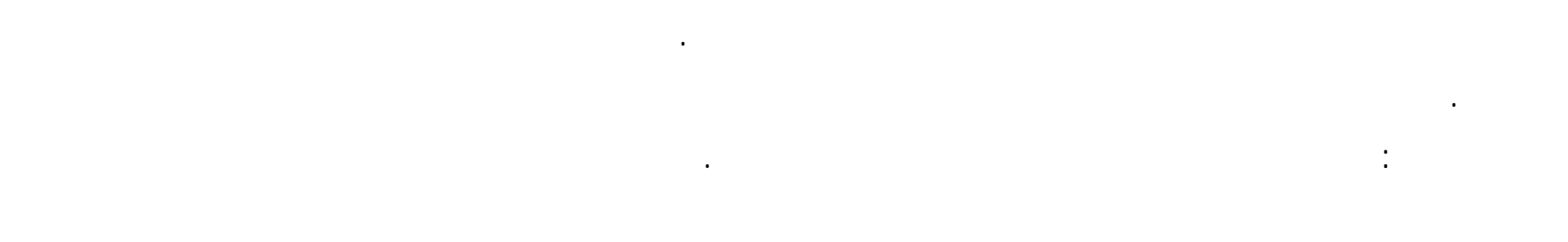

INTRODUCTION

Hydrazones of carboxylic acid hyraziedes $\left(\mathrm{RCONHN}=\mathrm{CHR}^{\prime}\right)$ are versatile ligands and have applications in many fields. Aroyl hydrazones are quite interesting ligands as they present a combination of donor sites, such as amide oxygen atom, imine nitrogen atom of the hydrazone moiety and an additional donor site (usually $\mathrm{N}$ or $\mathrm{O}$ ) provided from the aldehyde or ketone forming them. Hydrazones have interesting ligation properties due to the presence of these several coordination sites, hence they display versatility in metal coordination (Li et al., 2016 ; Singh et al., 2015). The mode of coordination depends on the nature of the central metal atom, the $\mathrm{pH}$ of the medium, the nature of the substituents and also on the position of the hydrazone group relative to other moieties. Moreover, deprotonation of the $-\mathrm{NH}$ group, which is readily achieved in the complexed ligand in particular, results in the formation of tautomeric anionic species, having new coordination properties (Singh, et al., 2013). They can act as bidentate, tridentate or tetradentate ligands depending on the nature of substituents attached to the hydrazone unit. Metal complexes of aroylhydrazone ligands have an attractive area of research because of their versatile coordination chemistry and a capability to generate varied molecular architecture and geometry (Banerjee et al., 2008; Kobayashi et al., 2014; Cindrić et al., 2017; Kendur et al., 2018).

Hydrazones readily form stable complexes with transition metals (Singh et al., 2013 ; Saif, et al., 2016), lanthanides (Ajlouni, et al., 2016), as well as main group elements (Pilóa et al., 2015). They form a wide variety of complexes with chemical, structural, biological and industrial importance. Metal complexes of hydrazones have been proven to show potential applications as catalysts (Sadhukhan et al., 2011), luminescent probes (Guo et al., 2011) and fluorescent sensors (Mukherjee et al., 2011). Their complexes with transition metal ions are known to provide useful models for elucidation of the mechanism of enzyme inhibition by hydrazine derivatives and for their pharmacological applications (Dilworth, 1976). They also have a variety of applications in biological, analytical and clinical fields, such as anti-bacterial, anti-fungal, anti-convulsing,anti-inflammatory, anti-malarial, analgesic, antiplatelets, anti-tuberculosis, anti-cancer and insecticidal activities (Rollas and Kücükgüzel, 2007; Suvarapu et al., 2012 ; Marella et al., 2014 ; Saif et al., 2016). Furthermore, metal complexes with hydrazones present DNA binding and cleavage activities (Banerjee et al., 2009 ; Gama et al., 2011). In view of the significant role played by the metal complexes of aroylhydrazones in biological systems, catalysis and in various other fields, we were motivated to synthesize $\mathrm{Co}(\mathrm{II}), \mathrm{Ni}(\mathrm{II}), \mathrm{Cu}$ (II) and $\mathrm{Zn}$ (II) complexes with hydrazones derived from 4-methyl benzoyl hydrazine, acetyl hydrazine, and picolinoyl hydrazine with the biologically active ketone (Paeonol), 2-hydroxy-4-methoxy acetophenone, (Fukuhara and Yoshida, 1987) (Scheme 1), and to describe their structures, spectroscopic, and magnetic properties. 


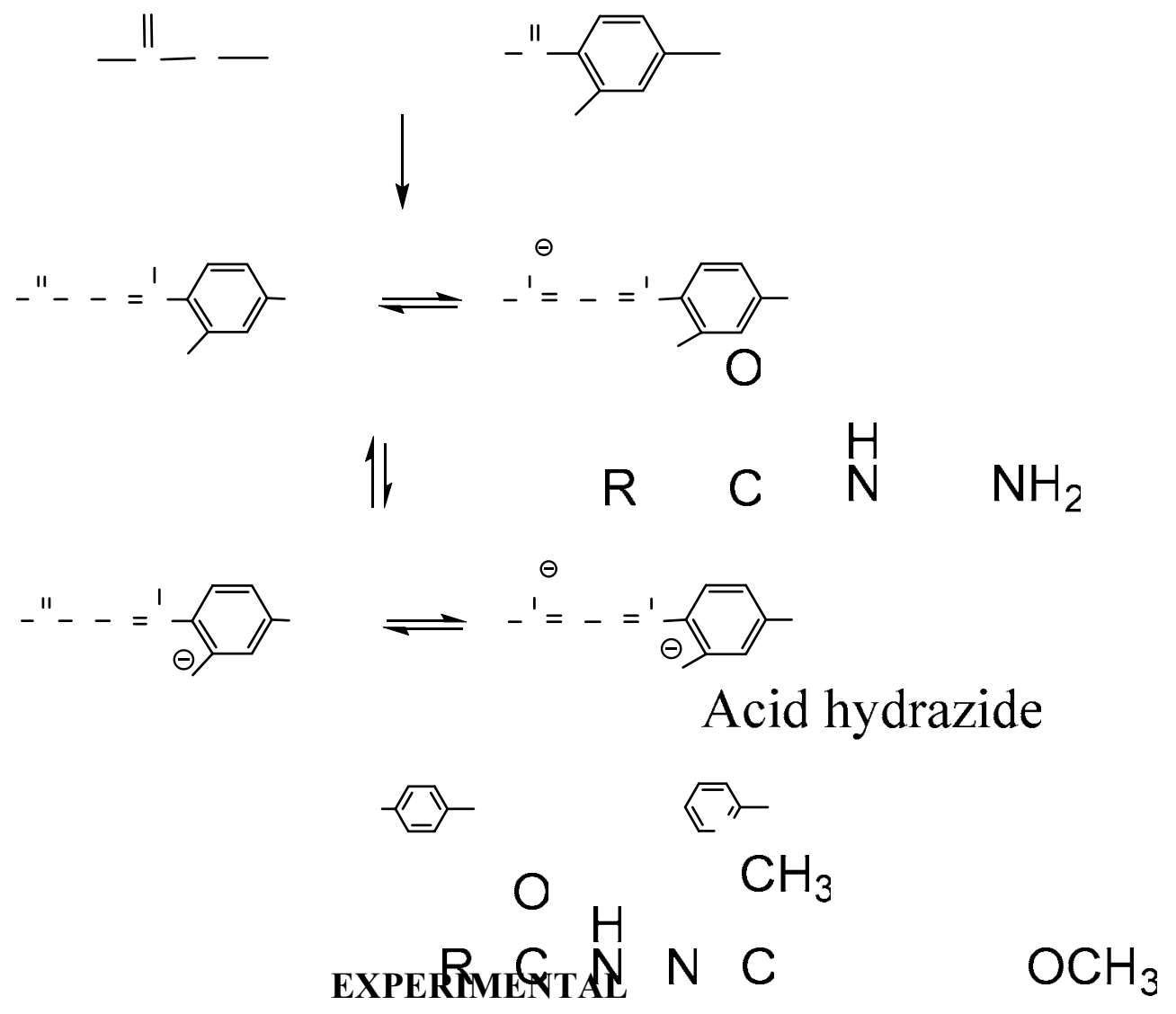

Material and measurements:

All chemicals used were reagent grade from B.D.H., Fluka or Merck chemical companies, used as supplied. The infrared spectra $(4000-400) \mathrm{cm}^{-1}$ of the ligands ard Eomplexes were recorded on Tensor 27 Bruker spectrophotometer as KBr discs. The UV-Vis spectra (1100-200) nm were recorded at room temperature on Labo Med, inc $1650 \mathrm{Pc}$ spectrophotometer curettes. Molar conductance's of the complexes were determined in absolute ethanol and DMF $\left(10^{-3} \mathrm{M}\right.$ solutions) at room temperature using PMC3 Jenway conductivity meter. Magnetic susceptibilities were measured with Gouy balance Sherwood scientific Cambridge at ambient temperature. The neçssary-H diamagnetic corrections for ligands were done using Pascal's tables. Melting points were obtained on 9300 Electrothermal melting point apparatus in open capillaries. The C.H.N. elemental analyses were performed on Euoro EA 3000 Instrument. The metal content of complexes was determined spectrophotometrically using SENSAA, GBC scientific equipment atomic absorption spectrometer (Co and $\mathrm{Cu}$ ) and complex metric titration using standard EDrA solution (Fiand Zn ) (Vogel, 1989).

\section{- $\quad$ Synthesis of acid hydrazides}

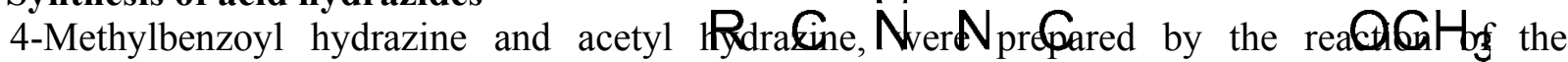
corresponding ethyl esters with hydrazine hydrate as described previously (Al-Saady and Al-Daher, 2000). Picolinoyl hydrazine was prepared from ethyl picolinate as described by (Zareef et al., 2006).

\section{- Synthesis of hydrazones}

These were prepared according to the literature method (Abd El-Motaleb et al., 2005), by reacting equimolar amounts of 2-hydroxy-4-methoxy acetophenone and acid hydrazide in apsplute ethanol as shown in Scheme 1.

A solution of acid hydrazide (0.01 mole) [1.55 g, 4-methylbenzoyl hydrazine,.0.8 g, acetyl

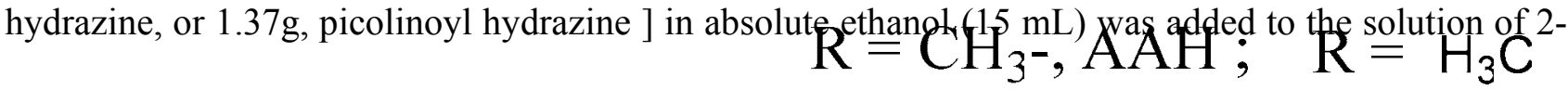


hydroxy-4-methoxy acetophenone $(1.66 \mathrm{~g}, 0.01 \mathrm{~mol})$ in absolute ethanol $(15 \mathrm{~mL})$ and few drops of glacial acetic acid as catalyst. The reaction mixture was stirred and boiled under reflux for $3 \mathrm{hrs}$.After completion of reaction and partial removal of solvent, the white crystalline solids that precipitated on cooling were separated by filtration, washed with cold ethanol $(5 \mathrm{~mL})$ then with ether $(5 \mathrm{~mL})$ and dried in an oven at $\left(80-70{ }^{\circ} \mathrm{C}\right)$.

\section{Synthesis of the Metal Complexes}

To the stirred hot ethanolic solution $(20 \mathrm{~mL})$ of the appropriate metal acetate $(0.001 \mathrm{~mole})$ [0.249g, $\mathrm{Co}\left(\mathrm{CH}_{3} \mathrm{COO}\right)_{2} .4 \mathrm{H}_{2} \mathrm{O} ; 0.249 \mathrm{~g}, \mathrm{Ni}\left(\mathrm{CH}_{3} \mathrm{COO}\right)_{2} .4 \mathrm{H}_{2} \mathrm{O} ; 0.199 \mathrm{~g}, \mathrm{Cu}\left(\mathrm{CH}_{3} \mathrm{COO}\right)_{2} . \mathrm{H}_{2} \mathrm{O} ; 0.219 \mathrm{~g}$, $\left.\mathrm{Zn}\left(\mathrm{CH}_{3} \mathrm{COO}\right)_{2} .2 \mathrm{H}_{2} \mathrm{O}\right]$ was added $(0.596 \mathrm{~g}, 0.002 \mathrm{~mole})$ of the ligand $(\mathrm{AMBH}),(0.444 \mathrm{~g}, 0.002 \mathrm{~mole})$ of the ligand (AAH) or $(0.57 \mathrm{~g}, 0.002$ mole $)$ of the ligand $(\mathrm{APH})$ in absolute ethanol $(10 \mathrm{~mL})$ and $(0.2 \mathrm{~g}$, 0.002 mole) of the organic base triethylamine. The reaction mixture was then heated under reflux with constant stirring for $3 \mathrm{hrs}$ upon which the solid complexes were separated, filtered off and washed with ethanol $(5 \mathrm{~mL})$ and dried as above.

\section{Antibacterial Activity:}

Antibacterial activity was evaluated using agar diffusion method (Kethcum, 1988). gramnegative bacteria viz. Salmonella typhi, Aeromonas, Klebsiella, Escherichia coli, Pseudomonas acruginosa and Morganella morganii as well as gram-positive bacteria viz. Staphylococcus aureus and Enterococcus faecalis were cultivated in nutrient agar on petri dishes. The test solution was prepared by dissolving $(100 \mathrm{mg})$ of the tested substances in DMSO $(1 \mathrm{~mL})$. A $6 \mathrm{~mm}$ diameter filter discs were socked in the tested solutions. After $2 \mathrm{~h}$ cultivation at $37{ }^{\circ} \mathrm{C}$, diameter of zones of inhibition was determined. DMSO was inactive under applied conditions.

\section{RESULTS AND DISCUSSION}

The hydrazones of acid hydrazides (4-methylbenzoyl hydrazine, acetyl hydrazine and picolinoyl hydrazine) (AMBH, AAH, and APH respectively) were prepared in good yields by condensation with 2-hydroxy-4-methoxy acetophenone (Scheme 1). The reaction of these hydrazones with metal acetates in presence of triethyl amine (Sadhukhan et al., 2011) yield bis-complexes of the general composition $\left[\mathrm{M}(\mathrm{L}-\mathrm{H})_{2}\right] \cdot \mathrm{nH}_{2} \mathrm{O}(\mathrm{L}=\mathrm{AMBH}, \mathrm{AAH}, \mathrm{APH} ; \mathrm{n}=0,1,2)$, in which the ligands deprotonated during complexation with the metals (II) as indicated by analytical data (Table 1 and 2). Most of the metal complexes are colored powdery non-hygroscopic solids. They are generally insoluble in water and nonpolar organic solvents, like chloroform, benzene and diethyl ether, but are slightly soluble in ethanol and methanol, and more soluble in highly polar organic solvents, like DMF and DMSO. The low molar conductance values of the solutions of the complexes in absolute ethanol $\left(2.2-11.5 \mathrm{ohm}^{-1} \mathrm{~mol}^{-1} \mathrm{~cm}^{2}\right)$ and in DMF (7.2-24.5 $\left.\mathrm{ohm}^{-1} \mathrm{~mol}^{-1} \mathrm{~cm}^{2}\right)$ indicating that they are non-electrolyte (Geary, 1971). 
Table 1 : Some physical properties and analysis data of the ligands and their complexes

\begin{tabular}{|c|c|c|c|c|c|c|c|c|}
\hline \multirow{2}{*}{$\begin{array}{l}\text { Comp. } \\
\text { No. }\end{array}$} & \multirow{2}{*}{ Formula } & \multirow{2}{*}{ Color } & \multirow{2}{*}{$\begin{array}{l}\text { Mp. } \\
\left(C^{0}\right)\end{array}$} & \multirow{2}{*}{$\begin{array}{c}\text { Yield } \\
\%\end{array}$} & \multicolumn{2}{|c|}{ Metal \% } & \multicolumn{2}{|c|}{$\Omega_{1}{ }_{1}^{-1} \mathrm{~cm}^{2} \mathrm{~mol}$} \\
\hline & & & & & Calc. & Found & $\mathrm{EtOH}$ & DMF \\
\hline $\mathrm{L}_{1}$ & $\begin{array}{c}\mathrm{AMBH}\left(\mathrm{C}_{17} \mathrm{H}_{18} \mathrm{~N}_{2} \mathrm{O}_{3}\right) \\
\text { M.wt }=298\end{array}$ & White & $88-90$ & 58 & ...... & ....... & ....... & ...... \\
\hline 1 & {$\left[\mathrm{C}_{\mathrm{O}}(\mathrm{AMBH}-\mathrm{H})_{2}\right] \cdot \mathrm{H}_{2} \mathrm{O}$} & Brown & $210-212$ & 52 & 8.78 & 9.49 & 6.9 & 9.7 \\
\hline 2 & {$\left[\mathrm{Ni}(\mathrm{AMBH}-\mathrm{H})_{2}\right]$} & Orange & $258-260$ & 71 & 8.9 & 8.4 & 6.4 & 13.4 \\
\hline 3 & {$\left[\mathrm{Cu}(\mathrm{AMBH}-\mathrm{H})_{2}\right] \cdot \mathrm{H}_{2} \mathrm{O}$} & Grey & $290 \mathrm{~d}$ & 83 & 9.66 & 10.17 & 5.4 & 8.8 \\
\hline 4 & {$\left[\mathrm{Zn}(\mathrm{AMBH}-\mathrm{H})_{2}\right]$} & White & $300 \mathrm{~d}$ & 62 & 9.9 & 10.4 & 4.6 & 15.2 \\
\hline $\mathrm{L}_{2}$ & $\begin{array}{c}\mathrm{AAH}\left(\mathrm{C}_{11} \mathrm{H}_{11} \mathrm{~N}_{2} \mathrm{O}_{3}\right) \\
\mathrm{M} . \mathrm{wt}=222\end{array}$ & Yellow & $168-170$ & 91 & ----- & ----- & ----- & ----- \\
\hline 5 & {$\left[\mathrm{C}_{\mathrm{O}}(\mathrm{AAH}-\mathrm{H})_{2}\right]$} & Orange & $250 \mathrm{~d}$ & 89 & 11.76 & 12.14 & 8.6 & 9.6 \\
\hline 6 & {$\left[\mathrm{Ni}(\mathrm{AAH}-\mathrm{H})_{2}\right] .2 \mathrm{H}_{2} \mathrm{O}$} & Green & $258 \mathrm{~d}$ & 85 & 11.7 & 11.9 & 7.4 & 10.9 \\
\hline 7 & {$\left[\mathrm{Cu}(\mathrm{AAH}-\mathrm{H})_{2}\right] \cdot \mathrm{H}_{2} \mathrm{O}$} & Green & $274 d$ & 87 & 12.14 & 12.09 & 3.2 & 7.9 \\
\hline 8 & {$\left[\mathrm{Zn}(\mathrm{AAH}-\mathrm{H})_{2}\right]$} & White & $290 \mathrm{~d}$ & 94 & 12.8 & 13.3 & 5.1 & 23.6 \\
\hline $\mathrm{L}_{3}$ & $\begin{array}{c}\mathrm{APH}\left(\mathrm{C}_{15} \mathrm{H}_{15} \mathrm{~N}_{3} \mathrm{O}_{3}\right) \\
\text { M.wt }=285 \\
\end{array}$ & Yellow & $178-180$ & 80 & ------ & ------ & ----- & ----- \\
\hline 9 & {$\left[\mathrm{C}_{\mathrm{O}}(\mathrm{APH}-\mathrm{H})_{2}\right]$} & Brown & $230-232$ & 95 & 9.39 & 9.84 & 11.5 & 24.5 \\
\hline 10 & {$\left[\mathrm{Ni}(\mathrm{APH}-\mathrm{H})_{2}\right]$} & Yellow & $200 \mathrm{~d}$ & 78 & 9.36 & 9.1 & 2.8 & 12.8 \\
\hline 11 & {$\left[\mathrm{Cu}(\mathrm{APH}-\mathrm{H})_{2}\right] \cdot \mathrm{H}_{2} \mathrm{O}$} & Green & $276 \mathrm{~d}$ & 84 & 10.02 & 9.67 & 2.2 & 8.6 \\
\hline 12 & {$\left[\mathrm{Zn}(\mathrm{APH}-\mathrm{H})_{2}\right]$} & Yellow & $250 \mathrm{~d}$ & 86 & 10.3 & 10.5 & 2.2 & 7.2 \\
\hline
\end{tabular}

$\mathrm{d}=$ decomposition temperature

Table 2: Elemental analyses of some of the synthesized complexes

\begin{tabular}{|c|c|c|c|c|c|}
\hline \multirow[t]{2}{*}{ Compd. No. } & \multirow[t]{2}{*}{ Abbreviation } & \multirow[t]{2}{*}{ Formula } & \multicolumn{3}{|c|}{$\begin{array}{l}\text { Elemental analyses } \\
\text { Calculated/(Found) }\end{array}$} \\
\hline & & & C\% & H\% & $\mathbf{N \%}$ \\
\hline 3 & {$\left[\mathrm{Cu}(\mathrm{AMBH}-\mathrm{H})_{2}\right] . \mathrm{H}_{2} \mathrm{O}$} & $\mathrm{C}_{34} \mathrm{H}_{34} \mathrm{~N}_{4} \mathrm{O}_{7} \mathrm{Cu}$ & $\begin{array}{c}60.3 \\
(59.22) \\
\end{array}$ & $\begin{array}{c}5.3 \\
(5.31) \\
\end{array}$ & $\begin{array}{c}10.28 \\
(10.80) \\
\end{array}$ \\
\hline 6 & {$\left[\mathrm{Ni}(\mathrm{AAH}-\mathrm{H})_{2}\right] .2 \mathrm{H}_{2} \mathrm{O}$} & $\mathrm{C}_{22} \mathrm{H}_{34} \mathrm{~N}_{4} \mathrm{O}_{8} \mathrm{Ni}$ & $\begin{array}{c}49.2 \\
(49.16)\end{array}$ & $\begin{array}{c}5.9 \\
(5.26)\end{array}$ & $\begin{array}{c}10.44 \\
(10.49)\end{array}$ \\
\hline 11 & {$\left[\mathrm{Cu}(\mathrm{APH}-\mathrm{H})_{2}\right] \cdot \mathrm{H}_{2} \mathrm{O}$} & $\mathrm{C}_{30} \mathrm{H}_{30} \mathrm{~N}_{6} \mathrm{O}_{7} \mathrm{Cu}$ & $\begin{array}{c}55.42 \\
(54.72)\end{array}$ & $\begin{array}{c}4.61 \\
(4.04)\end{array}$ & $\begin{array}{c}12.93 \\
(12.43)\end{array}$ \\
\hline
\end{tabular}

\section{Infrared Spectra}

In order to study the bonding mode of ligand to metal in the complexes, IR spectrum of the free ligand was compared with the spectra of metal complexes. The structurally significant IR bands for free ligands and their complexes have been reported in (Table 3). Remarkable differences between the IR spectra of the ligands and those of the corresponding complexes were observed. The IR spectral bands observed at the ranges (3336-3198), (3145 - 3076), (1695 - 1663), (1625 - 1610), (1263-1259) and $(974-951) \mathrm{cm}^{-1}$ in the spectra of the free ligands are assigned to the phenolic $\mathrm{v}(\mathrm{O}-\mathrm{H}), \mathrm{v}(\mathrm{N}-\mathrm{H}), \mathrm{v}$ $(\mathrm{C}=\mathrm{O}), \boldsymbol{v}(\mathrm{C}=\mathrm{N}), \boldsymbol{v}(\mathrm{C}-\mathrm{O})$ and $\cup(\mathrm{N}-\mathrm{N})$ respectively (Swathy et al., 2016 ; Ramesh et al., 2012). The disappearance of phenolic $\mathrm{U}(\mathrm{OH})$ band in all the metal complexes indicates the deprotonation of the phenolic-OH group and coordination through a phenolate oxygen. The appearance of $v(\mathrm{C}-\mathrm{O})^{-}$bands in the spectra of the complexes in the range (1349-1311) $\mathrm{cm}^{-1}$, suggests the bonding of ligand through a deprotonated $(\mathrm{C}-\mathrm{O})^{-}$phenolate group to the metal (Singh et al., 2013 ; Swathy et al., 2016). The 0 $(\mathrm{C}=\mathrm{O})$ band observed at $(1664$ and 1663$) \mathrm{cm}^{-1}$ in the spectra of the ligands AMBH and AAH, are shifted considerably to lower wave number by (54-8) $\mathrm{cm}^{-1}$, in its metal complexes, suggesting coordination through carbonyl oxygen (Singh et al., 2013 ; Guo et al., 2011). The $v(C=\mathrm{O})$ band in the spectra of the complexes of the ligand APH display no change or shift to higher frequency upon complexation with respect to free ligand. This denotes that the carbonyl oxygen atom is not involved in 
coordination in these complexes (El-Taras et al., 2012). The pyridine in-plane deformation mode observed at $(617) \mathrm{cm}^{-1}$ in the spectrum of the free ligand APH shifted to higher frequencies by (31-18) $\mathrm{cm}^{-1}$ in the spectra of its complexes suggesting coordination of the heterocyclic nitrogen atom (Despaigne et al., 2009). The $v(\mathrm{C}=\mathrm{N})$ band observed in the spectra of the free ligands shifted to lower frequency by(42-6) $\mathrm{cm}^{-1}$ in their metal complexes, indicating the involvement of the azomethine nitrogen in chelation with the metal ion (Singh et al., 2015). Coordination of nitrogen to the metal atom reduces the electron density in the azomethine group causing a shift in the $v_{(\mathrm{C}=\mathrm{N})}$ band to lower frequencies (Shit et al., 2009).

Furthermore, a medium band due to $\mathrm{v}(\mathrm{N}-\mathrm{N})$ observed in the spectra of the free ligands is shifted to higher frequencies by (42-6) $\mathrm{cm}^{-1}$ in their metal complexes indicating the coordination of one of the nitrogen atom of $>\mathrm{N}-\mathrm{N}<$ group with metal (Gawande et al., 2015 ; Singh et al., 2015). This phenomenon is owing to the diminution of the lone pair electrons repulsion which come from the two adjacent nitrogen atoms ,by sharing the electrons out to the metal ion (Shit et al., 2009). The v(NH) bands appearing at $(3145-3076) \mathrm{cm}^{-1}$ in the spectra of the free ligands shifted to higher frequencies in its metal complexes, probably due to decrease in hydrogen bonding on complexation, suggesting nonparticipation of $-\mathrm{NH}$ group in bonding. Their existence of $\mathrm{v}(\mathrm{C}=\mathrm{O})$ in the spectra of the complexes indicate that the ligands coordinated in the keto-form and enolization of the ligands on complexation is does not occur. The metal complexes also show a non-ligand bands in the (549-454) and (462-411) $\mathrm{cm}^{-}{ }^{1}$, ranges are tentatively assigned to $\mathrm{v}(\mathrm{M}-\mathrm{O})$ and $\mathrm{v}(\mathrm{M}-\mathrm{N})$, respectively (Singh et al., 2013). A broad band at ca. $3400 \mathrm{~cm}^{-1}$ is observed in the spectra of the complexes $(1,3,6,7$, and 11) which indicate the presence of lattice water (Sreejith et al., 2018). Since vibrational modes such as wagging, twisting and rocking activated by coordination to the metal have not been found in the expected ranges, it shows that water molecules are not coordinated (El-Taras et al., 2012).

On the basis of the above discussion, it may be concluded that in the complexes (1-8), of the ligands $\mathrm{AMBH}$ and $\mathrm{AAH}$ acts as anionic tridentate $\mathrm{ONO}$ donors, chelating through the carbonyl oxygen, the imine nitrogen and phenolate oxygen atoms. On the other hand, APH act as anionic tridentate ONN ligand in its complexes (9-12) coordinating through the phenolate oxygen atom in addition to the nitrogen atoms of the azomethine group and pyridine ring. A general structure for the metal complexes has been proposed Fig. (6).

Table 3 : Selected infrared frequencies of the ligands and their complexes

\begin{tabular}{|c|c|c|c|c|c|c|c|c|c|}
\hline Comp.No. & $v(\mathrm{O}-\mathrm{H})$ & $v(\mathrm{~N}-\mathrm{H})$ & $v(C=O)$ & $v(C=N)$ & $v(C-O)$ & $v(\mathrm{~N}-\mathrm{N})$ & $\delta$ (Py.ring) & $\mathrm{v}(\mathrm{M}-\mathrm{O})$ & $\mathbf{v}(\mathrm{M}-\mathrm{N})$ \\
\hline $\mathrm{L}_{1}$ & $3234_{(\mathrm{s}, \mathrm{b})}$ & $3145\left(_{\mathrm{sh})}\right.$ & $1664_{(\mathrm{s})}$ & $1616_{(\mathrm{s})}$ & $1263_{(\mathrm{s})}$ & $951_{(\mathrm{m})}$ & 2 & & \\
\hline 1 & - & $3168_{(\mathrm{m})}$ & $1648_{(\mathrm{s})}$ & $1593_{(\mathrm{s})}$ & $1356_{(\mathrm{s})}$ & $989_{(\mathrm{m})}$ & $\ldots \ldots$ & $466_{(\mathrm{m})}$ & $424_{(w)}$ \\
\hline 2 & - & $3168_{(\mathrm{m})}$ & $1656_{(\mathrm{s})}$ & $1610_{(\mathrm{vs})}$ & $1328_{(\mathrm{m})}$ & $987_{(\mathrm{m})}$ & $\ldots \ldots$ & $549_{(\mathrm{m})}$ & $422_{(\mathrm{m})}$ \\
\hline 3 & - & $3181_{(\mathrm{m})}$ & $1651_{(\mathrm{sh})}$ & $1608_{(\mathrm{s})}$ & $1354_{(\mathrm{s})}$ & $982_{(\mathrm{m})}$ & $\ldots \ldots$ & $498_{(\mathrm{m})}$ & $462_{(\mathrm{m})}$ \\
\hline 4 & - & $3191_{(\mathrm{m})}$ & $1656_{(\mathrm{m})}$ & $1588_{(\mathrm{vs})}$ & $1335_{(\mathrm{s})}$ & $978_{(\mathrm{m})}$ & $\ldots \ldots$ & $465_{(\mathrm{m})}$ & $443_{(\mathrm{m})}$ \\
\hline $\mathrm{L}_{2}$ & $3198_{(\mathrm{s}, \mathrm{b})}$ & $3101_{(\mathrm{m})}$ & $1663_{(\mathrm{vs})}$ & $1625_{(\mathrm{s})}$ & $1259_{(\mathrm{s})}$ & $974_{(\mathrm{m})}$ & $\ldots \ldots$ & $\ldots \ldots$ & $\ldots \ldots$ \\
\hline 5 & - & $3184_{(\mathrm{m})}$ & $1622_{(\mathrm{s})}$ & $1604_{(\mathrm{vs})}$ & $1342_{(\mathrm{s})}$ & $980_{(\mathrm{m})}$ & ...... & $505_{(\mathrm{m})}$ & $414_{(\mathrm{m})}$ \\
\hline 6 & - & $3171_{(\mathrm{m})}$ & $1617_{(\mathrm{sh})}$ & $1595_{(\mathrm{s})}$ & $1311_{(\mathrm{s})}$ & $985_{(\mathrm{m})}$ & $\ldots \ldots$ & $507_{(\mathrm{m})}$ & $448_{(\mathrm{w})}$ \\
\hline 7 & - & $3192_{(\mathrm{m})}$ & $1609_{(\mathrm{s})}$ & $1583_{(\mathrm{sh})}$ & $1335_{(\mathrm{m})}$ & $989_{(\mathrm{m})}$ & $\ldots \ldots$ & $489_{(\mathrm{m})}$ & $456_{(w)}$ \\
\hline 8 & - & $3157_{(\mathrm{m})}$ & $1620_{(\mathrm{s})}$ & $1593_{(\mathrm{vs})}$ & $1312_{(\mathrm{s})}$ & $993_{(\mathrm{sh})}$ & $\ldots \ldots$ & $507_{(\mathrm{m})}$ & $434_{(\mathrm{m})}$ \\
\hline $\mathrm{L}_{3}$ & $3336_{(\mathrm{s})}$ & $3076_{(\mathrm{m})}$ & $1695_{(\mathrm{s})}$ & $1610_{(\mathrm{s})}$ & $1261_{(\mathrm{s})}$ & $954_{(\mathrm{m})}$ & $617_{(\mathrm{m})}$ & & \\
\hline 9 & - & $3188_{(\mathrm{m})}$ & $1711_{(\mathrm{m})}$ & $1597_{(\mathrm{s})}$ & $1335_{(\mathrm{w})}$ & $985_{(\mathrm{m})}$ & $635_{(w)}$ & $457_{(\mathrm{m})}$ & $411_{(\mathrm{m})}$ \\
\hline 10 & - & $3210_{(\mathrm{m})}$ & $1696_{(\mathrm{m})}$ & $1596_{(\mathrm{s})}$ & $1349_{(\mathrm{s})}$ & $987_{(\mathrm{m})}$ & $638_{(\mathrm{m})}$ & $530_{(\mathrm{m})}$ & $451_{(\mathrm{m})}$ \\
\hline 11 & - & $3076_{(\mathrm{m})}$ & $1695_{(\mathrm{sh})}$ & $1602_{(\mathrm{s})}$ & $1338_{(\mathrm{sh})}$ & $996_{(\mathrm{m})}$ & $648_{(\mathrm{m})}$ & $536_{(\mathrm{w})}$ & $462_{(\mathrm{m})}$ \\
\hline 12 & - & $3207_{(\mathrm{m})}$ & $1691_{(\mathrm{m})}$ & $1597_{(\mathrm{s})}$ & $1341_{(\mathrm{m})}$ & $984_{(\mathrm{m})}$ & $639_{(w)}$ & $454_{(\mathrm{m})}$ & $422_{(\mathrm{m})}$ \\
\hline
\end{tabular}

vs=very strong, s=strong, $\mathrm{sh}=$ sholder, $\mathrm{m}=$ medium, $\mathrm{w}=$ weak, $\mathrm{b}=$ broad 


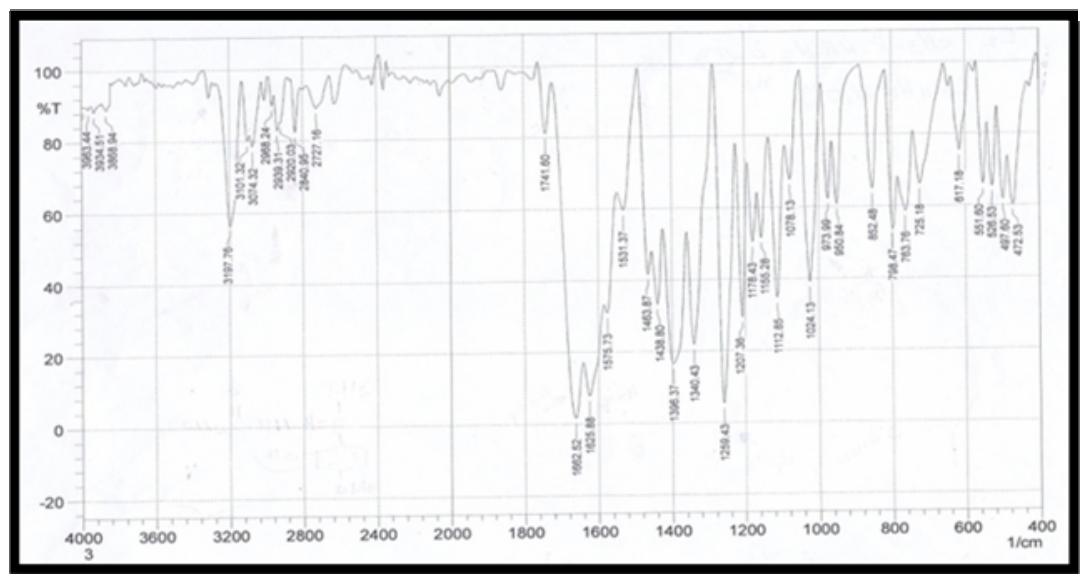

Fig. 1: Infrared spectrum of the ligand [AAH]

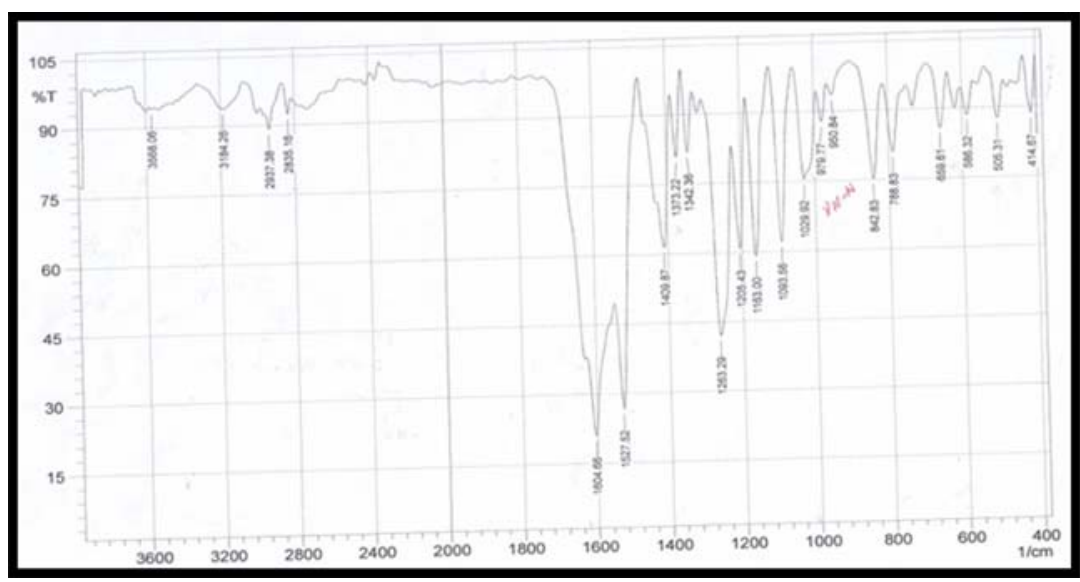

Fig. 2: Infrared spectrum of the complex $\left[\mathrm{Co}(\mathrm{AAH}-\mathrm{H})_{2}\right]$

\section{Electronic Spectra And Magnetic Moment Properties:}

The electronic spectra of ligands and their metal complexes in the rang (1100-200) nm, were carried out in DMF. Table (4) shows the electronic spectral bands and magnetic moments of the prepared complexes.

The spectra of the ligands in DMF solution exhibit two main absorption bands at (34602-32894) $\mathrm{cm}^{-1}$ and (31055-29940) $\mathrm{cm}^{-1}$. The first band probably is due to $\pi \rightarrow \pi^{*}$ transition of the chromophore $(-\mathrm{C}=\mathrm{N}-\mathrm{NH}-\mathrm{CO}-)$, and the second band might be attributed to the $\mathrm{n} \rightarrow \pi^{*}$ transitions resulting from nitrogen and oxygen atoms. In the spectra of the complexes, the shift of the ligand transitions to a longer wavelength (red shift) is ascribed to the ligand complextion with metal ions (El-Taras et al., 2012). The new intense band observed in the spectra of all complexes at the region $(27548-23148) \mathrm{cm}^{-1}$ may be associated with the charge transfer transitions (LMCT) (Ghosh et al., 2007).

The magnetic moment values of $\mathrm{Co}$ (II) complexes $(1,5,9)$ are in the range $(5.11-4.85)$ B.M, which are fairly close to the values reported for three unpaired electrons in an octahedral environment (Singh et al., 2013). These complexes exhibit three bands in their spectra at the regions (20366-19083) 
$\mathrm{cm}^{-1},(14925-14044) \mathrm{cm}^{-1}$ and (10204-9250) $\mathrm{cm}^{-1}$ indicating an octahedral geometry around the metal ion. These transitions are assigned as ${ }^{4} \mathrm{~T}_{1 \mathrm{~g}}(\mathrm{~F}) \rightarrow{ }^{4} \mathrm{~T}_{2 \mathrm{~g}}(\mathrm{P})\left(\mathbf{v}_{3}\right),{ }^{4} \mathrm{~T}_{1 \mathrm{~g}}(\mathrm{~F}) \rightarrow{ }^{4} \mathrm{~A}_{2 \mathrm{~g}}(\mathrm{~F})\left(\mathbf{v}_{2}\right)$ and ${ }^{4} \mathrm{~T}_{1 \mathrm{~g}}(\mathrm{~F}) \rightarrow{ }^{4} \mathrm{~T}_{2 \mathrm{~g}}(\mathrm{~F})$ $\left(\mathbf{v}_{1}\right)$, respectively (Bakale et al., 2018).

The magnetic moment values of $\mathrm{Ni}(\mathrm{II})$ complexes $(2,6,10)$ are in the range $(3.3-2.92) \mathrm{BM}$ which are close to the spin only value of two unpaired electrons, indicating octahedral environment around $\mathrm{Ni}(\mathrm{II})$ ion. It is further confirmed by their electronic spectral bands observed at the regions (23310-20080) $\mathrm{cm}^{-1}$, (16949-11235) $\mathrm{cm}^{-1}$ and (9523-9216) $\mathrm{cm}^{-1}$ assignable to ${ }^{3} \mathrm{~A}_{2 \mathrm{~g}}(\mathrm{~F}) \rightarrow{ }^{3} \mathrm{~T}_{1 \mathrm{~g}}(\mathrm{p})\left(\mathbf{v}_{3}\right)$, ${ }^{3} \mathrm{~A}_{2 \mathrm{~g}}(\mathrm{~F}) \rightarrow{ }^{3} \mathrm{~T}_{1 \mathrm{~g}}(\mathrm{~F})\left(\mathbf{v}_{2}\right)$ and ${ }^{3} \mathrm{~A}_{2 \mathrm{~g}}(\mathrm{~F}) \rightarrow{ }^{3} \mathrm{~T}_{2 \mathrm{~g}}(\mathrm{~F})\left(\mathbf{v}_{1}\right)$ transitions, respectively (El-Sonbati et al., 2016).

The electronic spectra of $\mathrm{Cu}(\mathrm{II})$ complexes $(3,7,11)$ contain a broad band at $(14814-13793) \mathrm{cm}^{-1}$. These bands are typical of $\mathrm{d}$ - $\mathrm{d}$ band of Jahn-Teller distorted $\mathrm{Cu}(\mathrm{II})$ complexes in distorted octahedral geometry, and can be assigned to two or three of the transitions ${ }^{2} \mathrm{~B}_{1 \mathrm{~g}} \rightarrow{ }^{2} \mathrm{E}_{\mathrm{g}},{ }^{2} \mathrm{~B}_{1 \mathrm{~g}} \rightarrow{ }^{2} \mathrm{~B}_{2 \mathrm{~g}}$ and ${ }^{2} \mathrm{~B}_{1 \mathrm{~g}} \rightarrow{ }^{2} \mathrm{~A}_{1 \mathrm{~g}}$ that resulted from splitting of the ${ }^{2} \mathrm{Eg} \rightarrow{ }^{2} \mathrm{~T}_{2} \mathrm{~g}$ (Rakha et al., 2014). Magnetic moment of these complexes are in range (2.01-1.74) B.M correspond to one unpaired electron and suggesting a monomeric octahedral geometry (Cotton et al., 1999).

The diamagnetic $\mathrm{Zn}(\mathrm{II})$ complexes $(4,8,12)$ show no prominent absorption in the visible region and the $\mathrm{Zn}(\mathrm{II})$ complexes were found to be diamagnetic in nature consistent because of $\mathrm{d}^{10}$ configuration of $\mathrm{Zn}(\mathrm{II})$; therefore, the structures of the prepared $\mathrm{Zn}$ (II) complexes were proposed depending on the data of other measurements namely metal content and I.R spectra (Cotton et al., 1999; Mishra et al., 2014).

Table 4 : Electronic spectra and magnetic moments data of the ligands and their complexes

\begin{tabular}{|c|c|l|}
\hline Complex No. & Meff $\mathbf{B . M}$ & \multicolumn{1}{|c|}{${\text { Electronic spectrum } \mathbf{~ c m}^{-1}}^{-1}$} \\
\hline $\mathrm{L}_{1}$ & $\ldots \ldots$ & 32894,30864 \\
\hline 1 & 4.85 & $31446,28490,27173,20366,14925,10204$ \\
\hline 2 & 3.3 & $31746,28571,23148,20080,11235,9216$ \\
\hline 3 & 1.87 & $32258,28089,25575,13985$ \\
\hline 4 & diamagnetic & $32670,29850,26246$ \\
\hline $\mathrm{L}_{2}$ & $\ldots \ldots$ & 34602,31055 \\
\hline 5 & 5.04 & $33557,28735,26881,19083,14814,9389$ \\
\hline 6 & 2.93 & $33112,28089,25510,20876,16129,9302$ \\
\hline 7 & 2.01 & $34482,31446,24691,14814$ \\
\hline 8 & diamagnetic & $33898,27932,26525$ \\
\hline $\mathrm{L}_{3}$ & $\ldots \ldots$ & 33112,29940 \\
\hline 9 & 5.11 & $32051,28571,27027,19920,14044,9250$ \\
\hline 10 & 2.92 & $32786,29069,24570,23310,16949,9523$ \\
\hline 11 & 1.74 & $32894,28409,27548,13793$ \\
\hline 12 & diamagnetic & \\
\hline
\end{tabular}

\section{Antibacterial Test}

The anti-bacterial studies were carried out using the disc diffusion method. All results are tabulated in (Table 5). Six types of gram-negative bacteria viz. Salmonella typhi, Aeromonas, Klebsiella, Escherichia coli, Pseudomonas acruginosa and Morganella morganii as well as two types of gram-positive bacteria viz. Staphylococcus aureus and Enterococcus faecalis were used as the test organisms. Based on the results, the ligands show low activity towards the bacteria. Generally, all of the complexes show higher antibacterial properties compared to the free hydrazone ligands and moderate activity compared to the antibiotic Ceftriaxone. 
It is suggested that the antimicrobial activity of the complexes is due to either killing the microbes or inhibiting their multiplication by blocking their active site.

Table 5 : Antibacterial activity of the tested compounds

\begin{tabular}{|c|c|c|c|c|c|c|c|c|c|}
\hline $\begin{array}{c}\text { Comp. } \\
\text { No. }\end{array}$ & Abbriv . & $\begin{array}{c}* \\
\text { Sal.typh. }\end{array}$ & $\begin{array}{c}* \\
\text { Aeromonas }\end{array}$ & $\begin{array}{c}* \\
\text { klebsiella }\end{array}$ & $\begin{array}{c}* \\
\text { E. Coli }\end{array}$ & $\begin{array}{c}* \\
\text { P. } \\
\text { acruginosa }\end{array}$ & $\begin{array}{c}* \\
\text { Morga } \\
\text { morganii }\end{array}$ & $\begin{array}{c}* \\
\text { S. } \\
\text { aureus }\end{array}$ & $\begin{array}{c}* \\
\text { E. } \\
\text { faecalis }\end{array}$ \\
\hline $\mathrm{L}_{1}$ & AMBH & $\mathrm{R}$ & $\mathrm{R}$ & $\mathrm{R}$ & $\mathrm{R}$ & $\mathrm{R}$ & $\mathrm{R}$ & $\mathrm{S}(30)$ & $\mathrm{R}$ \\
\hline 3 & {$\left[\mathrm{Cu}(\mathrm{AMBH}-\mathrm{H})_{2}\right] \cdot \mathrm{H}_{2} \mathrm{O}$} & $\mathrm{R}$ & $\mathrm{R}$ & $\mathrm{R}$ & $\mathrm{R}$ & $\mathrm{R}$ & $\mathrm{R}$ & $\mathrm{S}(11)$ & $\mathrm{R}$ \\
\hline 4 & {$\left[\mathrm{Zn}(\mathrm{AMBH}-\mathrm{H})_{2}\right]$} & $\mathrm{R}$ & $\mathrm{R}$ & $\mathrm{R}$ & $\mathrm{R}$ & $\mathrm{R}$ & $\mathrm{R}$ & $\mathrm{S}(20)$ & $\mathrm{R}$ \\
\hline $\mathrm{L}_{2}$ & AAH & $\mathrm{R}$ & $\mathrm{R}$ & $\mathrm{R}$ & $\mathrm{R}$ & $\mathrm{R}$ & $\mathrm{R}$ & $\mathrm{R}$ & $\mathrm{R}$ \\
\hline 7 & {$\left[\mathrm{Cu}(\mathrm{AAH}-\mathrm{H})_{2}\right] \cdot \mathrm{H}_{2} \mathrm{O}$} & $\mathrm{S}(9)$ & $\mathrm{R}$ & $\mathrm{R}$ & $\mathrm{S}(20)$ & $\mathrm{R}$ & $\mathrm{R}$ & $\mathrm{S}(22)$ & $\mathrm{R}$ \\
\hline 8 & {$\left[\mathrm{Zn}(\mathrm{AAH}-\mathrm{H})_{2}\right]$} & $\mathrm{S}(21)$ & $\mathrm{S}(12)$ & $\mathrm{R}$ & $\mathrm{S}(13)$ & $\mathrm{R}$ & $\mathrm{R}$ & $\mathrm{R}$ & $\mathrm{R}$ \\
\hline $\mathrm{L}_{3}$ & APH & $\mathrm{R}$ & $\mathrm{R}$ & $\mathrm{R}$ & $\mathrm{S}(22)$ & $\mathrm{R}$ & $\mathrm{S}(14)$ & $\mathrm{S}(13)$ & $\mathrm{R}$ \\
\hline 11 & {$\left[\mathrm{Cu}(\mathrm{APH}-\mathrm{H})_{2}\right] \cdot \mathrm{H}_{2} \mathrm{O}$} & $\mathrm{R}$ & $\mathrm{R}$ & $\mathrm{R}$ & $\mathrm{R}$ & $\mathrm{R}$ & $\mathrm{R}$ & $\mathrm{R}$ & $\mathrm{R}$ \\
\hline \multirow[t]{2}{*}{12} & {$\left[\mathrm{Zn}(\mathrm{APH}-\mathrm{H})_{2}\right]$} & $\mathrm{R}$ & $\mathrm{R}$ & $\mathrm{R}$ & $\mathrm{R}$ & $\mathrm{R}$ & $\mathrm{R}$ & $\mathrm{R}$ & $\mathrm{R}$ \\
\hline & Ceftriaxone & $\mathrm{R}$ & $\mathrm{R}$ & $\mathrm{R}$ & $\mathrm{S}(32)$ & $\mathrm{S}(28)$ & $\mathrm{S}(40)$ & $\mathrm{S}(30)$ & $\mathrm{R}$ \\
\hline
\end{tabular}

* =Inhibition diameter $(\mathrm{mm}), \mathrm{R}=$ Resistant, $\mathrm{S}=$ Susceptible

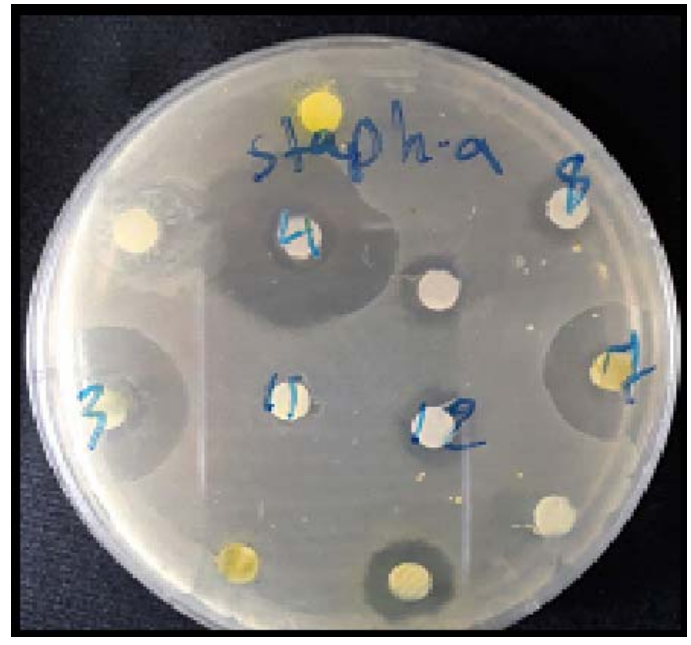

Fig.3: Photograph showing the (S.aureus) screening of the complexes $3,4,7,8,11,12$

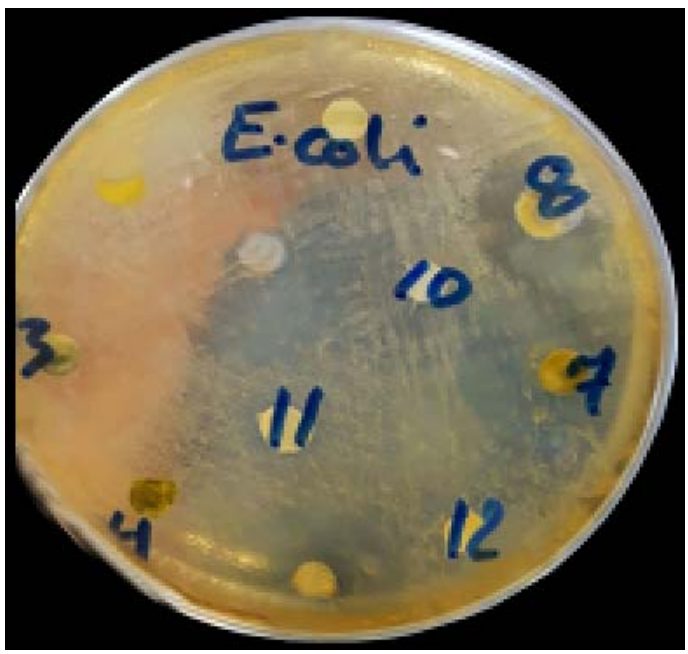

Fig.4: Photograph showing the antibacterial antibacterial (E.Coli) screening of the complexes $3,4,7,8,11,12$

\section{CONCLUSION}

Based on stoichiometries and spectro-chemical studies, the AMBH and AAH hydrazone ligands, act as a monobasic tridentate ligand $\mathrm{ONO}$ in their prepared deprotenated complexes (1-8) coordinating through the phenolate oxygen, azommethine nitrogen and carbonyl oxygen atoms. The ligand APH acts as a monobasic tridentate ligand $\mathrm{ONN}$ in its complexes (9-12) coordinating through the phenolate oxygen, azommethine nitrogen and pyridine ring nitrogen atoms. Octahedral geometry was proposed for all complexes Fig. (5), Fig. (6)

$\mathrm{Cu}(\mathrm{II})$ and $\mathrm{Zn}(\mathrm{II})$ complexes are tested against six Gram-negative and two Gram-positive bacteria. The exhibited moderate activity with respect to ceftriaxone antibiotic and higher activity than the free ligands. 


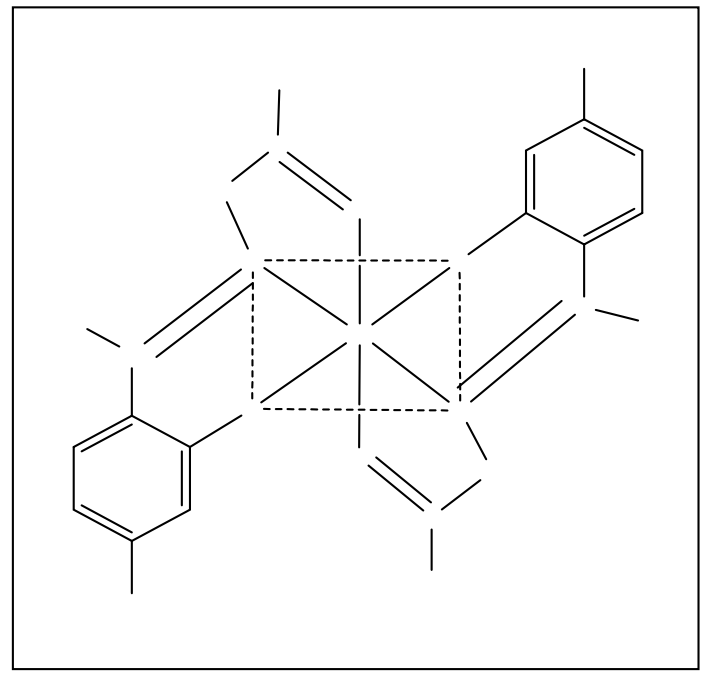

Fig. 5: Proposed structure for the complex (AMBH,AAH)

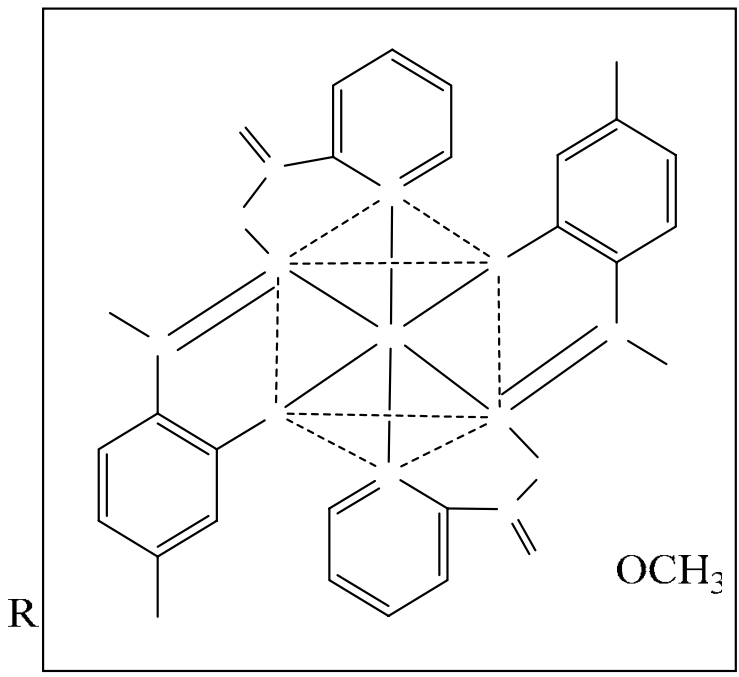

Fig. 6: Proposed structure for the complexes ( APH) $\mathrm{C}$

$$
\mathbf{M}=\mathrm{C}_{\mathrm{O}}(\mathrm{II}), \mathrm{Ni}(\mathrm{II}), \mathrm{Cu}(\mathrm{II}), \mathrm{Zn}(\mathrm{II})
$$

$\mathrm{N}$

\section{REFERENCES O}

Abd El-Motaleb, A.; Ramadan, M.; Issa, R.M. (2005). Synthesis, characterization and ascorbic acid oxidize mimetic catalytic activity of apper(II) picolyl hydrazone complexes. Trans. Met. Chem., 30, 471-480.

Ajlouni, A.M.; Abu-Salem, Q.; Taha1, Z.A.; Hijazi, A.K.; Al Momani, W. (2016). Synthesis, characterizatiof, Giological activities and luminesent properties of lanthanide complekes with [2-thiophenecarboxylic acid, 2-(2pyridinylmethylene)hydrazide] Schiff bases ligand. J. Rare Earths, 34, 986-993.

Al-Saady, S.K.; Al-Daher, A.G.M. (2000). Preparation and study of uranyl chloride complexes with some acid hydrazides. Iraqi J. Chem., 26 (2), 462-470.

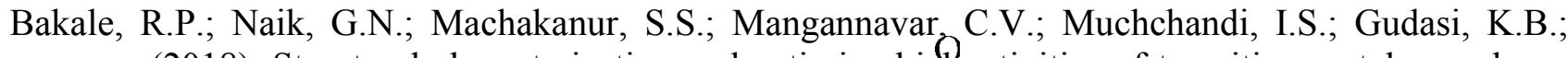
(2018). Structural characterization and antimicrobial activities of transition metal complexes of a hydrazone ligand. J. Mol. Struct., 1154, 92-99.

Banerjee, S.; Mondal, S.; Sen, S.; Das, S.; Hughes, D.L.; Rizzoli, C๕ Desplanches, C.; Mandal, C.; Mitra, S. (2009). Four new dinuclear $\mathrm{Cu}(\mathrm{II})$ hydrazone complexes using various organic spacers: syntheses, crystal structures, DNA binding and cleavage studies and selective cell inhibitory effect towards leukemic and normal lymphocytes. Balton Trans., 34, 6849-6860.

Banerjee, S.; Ray, A.; Sen, S.; Mitta S.; Hughes, D.L.; Butcher, R.J.; Batten, S.R.; Turner, D.R. (2008). Pseudohalide-induced structural varjations in hydrazone-based metal complexes:

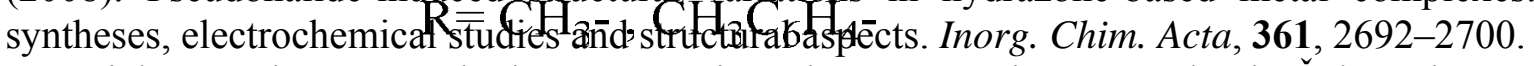

Cindrić, M.; Bjelopetrović, A.; Pavlović, G.; Damjanović, V.; Lovrić, J.; Matković-Čalogović, D.; Vrdoljak, V. (2017). Copper(II) complexes with benzhydrazone-related ligands: synthesis, structural studies and cytotoxicity assay. New J. Chem., 41, 2425-2435.

Cotton, F.A.; Wilkinson, G.; Murillo, C.A.; Bochmann, M. (1999). "Advanced Inorganic Chemistry ". $6^{\text {th }}$ ed., John Wiley and Sons, New York, pp. 810-842. 
Despaigne, A.R.; Dasilva, J.G.; Docarmo, A.C.; Piro, O.E.; Castellano, E.E.; Beraldo, H. (2009). Copper(II) and Zinc(II) complexes with 2-benzoylpyridine-methyl hydrazone. J. Mol. Struct., 920, 97-102.

Dilworth J.R. (1976). The coordination chemistry of substituted hydrazines. Coord. Chem. Rev., 21, $29-62$.

El-Sonbati, A.Z.; Diab, M.A.; El-Bindary, A.A.; Abou-Dobara M.I.; Seyam, H.A. (2016). Molecular docking, DNA binding, thermal studies and antimicrobial activities of Schiff base complexes. J. Mol. Liq., 218, 434-456.

El-Taras, A.A.; EL-Mehasseb, I.M.; Ramadan, A.M. (2012). Synthesis, characterization, magnetic, thermal and electrochemical studies of oxidovanadium (IV) picolyl hydrazones as functional catecholoxidase models. C. R. Chimie., 15, 298-310.

Fukuhara, Y.; Yoshida, D. (1987). Paeonol: a bio-antimutagen isolated from a crude drug, moutan cortex. Agric. Biol. Chem., 51(5), 1441 -1442.

Gama, S.; Mendes, F.; Marques, F.; Santos, I.C.; Carvalho, M.F.; Correia, I.; Pessoa, J.C.; Santos, I.; Paulo, A. (2011). Copper(II) complexes with tridentate pyrazole-based ligands: synthesis, characterization, DNA cleavage activity and cytotoxicity. J. Inorg. Biochem., 105, 637-644.

Gawande, P.U.; Mandlik, P.R.; Aswar, A.S. (2015). Synthesis and characterization of Cr(III), Mn(III), $\mathrm{Fe}(\mathrm{III}), \mathrm{VO}(\mathrm{IV}), \mathrm{Zr}(\mathrm{IV})$ and UO2(VI) complexes of Schiff base derived from isonicotinoyl hydrazone. Indian J. Pharm. Sci., 77(4), 376-381.

Geary, W.J. (1971). The use of conductivity measurement in organic solvents for the characterization of coordination compounds. Coord. Chem. Rev., 7, 81-122.

Ghosh, T.; Mondal, B.; Gosh, T.; Sutradhar, M.; Mukherjee, G.; Drew, M.G.B. (2007). Synthesis, structure, solution chemistry and the electronic effect of para substituents on the vanadium center in a family of mixed-ligand $[\mathrm{VVO}(\mathrm{ONO})(\mathrm{ON})]$ complexes. Inorg. Chem. Acta, 360, $1753-1761$.

Guo, D.; Wu, P.; Tan, H.; Xia, L.; Zhou, W. (2011). Synthesis and luminescence properties of novel 4(N-carbazolemethyl) benzoyl hydrazine Schiff bases. J. Luminescence, 131, 1272-1276.

Kendur, U.; Chimmalagi, G.H.; Patil, S.M.; Gudasi, K.B.; Frampton, C.S.; Mangannavar, C.V.; Muchchandi, I.S. (2018). Mononuclear late first row transition metal complexes of ONO donor hydrazone ligand: Synthesis, characterization, crystallographic insight, in vivo and in vitro anti-inflammatory activity. J. Mol. Struct., 1153, 299-310.

Kethcum, P.A. (1988). "Microbiology: Concept and Applications". John Wiley and Sons, New York. $384 \mathrm{p}$.

Kobayashi, A.; Yamamoto, D.; Horiki, H.; Sawaguchi, K.; Matsumoto, T.; Nakajima, K.; Chang, H. C.; Kato, M. (2014). Photoinduced dimerization reaction coupled with oxygenation of a platinum(II)-hydrazone complex. Inorg. Chem., 53, 2573-2581.

Li, L.; Zhang, Y.Z.; Liu, E.; Yang, C.; Golen, J.A.; Rheingold, A.L.; Zhang, G. (2016). Synthesis and structural characterization of zinc(II) and cobalt(II) complexes based on multidentate Hydrazone ligands. J. Mol. Struct., 1110, 180-184.

Marella, A.; Shaquiquzzaman, M.; Akhtar, M.; Verma, G.; Ali, M.R.; Alam, M.M. (2014). A review exploring biological activities of hydrazones. J. Bioallied Sci., 6(2), 69-80.

Mishra, M.; Tiwari, K.; Shukla, S.; Mishra, R.; Singh, V.P. (2014). Synthesis, structural investigation, DNA and protein binding study of some $3 \mathrm{~d}$ metalcomplexes with N'-(phenyl-pyridin-2-ylmethylene)-thiophene-2-carboxylic. Spectroch. Acta, A: Molec. and Biomolec., 132, 452-464.

Mukherjee, S.; Chowdhury, S.; Paul, A. K.; Banerjee, R. (2011). Selective extraction of palladium(II) using hydrazine ligand: Anovel fluorescent sensor. J. Luminescence, 131, 2342-2346. 
Pilóa, E.D.L.; Recio-Despaignea, A.A.; Da Silvab, J.G.; Ferreiraa, I.P.; Takahashia, J.A.; Beraldoa, H. (2015). Effect of coordination to antimony(III) on the antifungal activity of 2-acetylpyridineand 2-benzoylpyridine-derived hydrazones. Polyhedron, 97, 30-38.

Rakha, T.H.; El-Gammal, O.A.; Metwally, H.M.; Abu El-Reash, G.M. (2014). Synthesis, characterization, DFT and biological studies of (Z)-N0-(2-oxoindolin-3-ylidene) picolino hydrazide and its $\mathrm{Co}(\mathrm{II}), \mathrm{Ni}(\mathrm{II})$ and $\mathrm{Cu}(\mathrm{II})$ complexes. J. Mol. Struct., 1062, 96-109.

Ramesh, G.N.; Rao, Y.S.; Prathima, B.; Sravani, V.; Reddy, A.V. (2012). Synthesis, characterization and biological activities of manganese(II) complex: molecular modeling of DNA interactions. Der. Pharm. Let., 4(4), 1299-1307.

Rollas, L.; Kücükgüzel, S.G. (2007). Biological activities of hydrazone derivatives. Molecules, 12, 1910-1919.

Sadhukhan, D.; Ray, A.; Pilet, G.; Rizzoli, C.; Rosair, G.M.; Gomez-García, C.J.; Signorella, S.; Bellu, S.; Mitra, S. (2011). Weak interactions modulating the dimensionality in supramolecular architectures in three new nickel(II)-hydrazone complexes, magneto structural correlation, and catalytic potential for epoxidation of alkenes under phase transfer conditions. Inorg. Chem., 50, 8326-8339.

Saif, M.; El-Shafiy, H.F.; Mashaly, M.M.; Eid, M.F.; Nabeel, A.I.; Fouad, R. (2016). Synthesis, characterization, and antioxidant/cytotoxic activity of new chromone Schiff base nanocomplexes of $\mathrm{Zn}(\mathrm{II}), \mathrm{Cu}(\mathrm{II}), \mathrm{Ni}(\mathrm{II})$ and $\mathrm{Co}(\mathrm{II})$. J. Mol. Struct., 1118, 75-82.

Shit, S.; Samanta, C.B.; Slawin, A.M.Z.; Gramlich, V.; Mitra, S. (2009). Three new coordination complexes of cobalt(III), manganese(II), and copper(II) with N,N,O-donor hydrazine ligands: syntheses and structural characterizations. Struct. Chem., 20, 633-642.

Singh, P.; Singh, I.P.; Tiwari, K.; Mishra, M.; Singh, A.K.; Singh, V.P.(2015). Synthesis, structural investigations and corrosion inhibition studies on $\mathrm{Mn}(\mathrm{II}), \mathrm{Co}(\mathrm{II}), \mathrm{Ni}(\mathrm{II}), \mathrm{Cu}(\mathrm{II})$ and $\mathrm{Zn}$ (II) complexes with 2-amino-benzoic acid (phenyl-pyridin-2-yl-methylene)-hydrazide. RSC Adv., 5, 45217-45230.

Singh, V.P.; Singh, S.; Singh, D.P.; Singh, P.; Tiwari, K.; Mishra, M.; Butcher, R.J. (2013). Synthesis, spectral and single crystal X-ray diffraction studies on $\mathrm{Co}(\mathrm{II}), \mathrm{Ni}(\mathrm{II}), \mathrm{Cu}(\mathrm{II})$ and $\mathrm{Zn}$ (II) complexes with o-amino acetophenone benzoyl hydrazone. Polyhedron, 56, 71-81.

Sreejith, S.S.; Nair, A.; Smolenski, V.A.; Jansinski, J.P.; Kurup, M.R.P. (2018). Cd(II) and Ni(II) complexes from aroyl hydrazones: Unravelling the intermolecular interactions and electronic, crystal structures through experimental and theoretical studies. Inorg. Chim, Acta., 469, 264279.

Suvarapu, L.N.; Seo, Y.; Baek, S.; Ammireddy, V.R. (2012). Review on analytical and biological applications of hydrazones and their metal complexes. E-J. Chem., 9(3), 1288-1304.

Swathy, S. S.; Joseyphus, R. S.; Nisha, V. P.; Subhadrambika, N. (2016). Synthesis, spectroscopic investigation and antimicrobial activities of some transition metal complexes of a [(2-hydroxy acetophenone)-3-isatin]-bishydrazone. Arab. J. Chem., 9, S1847-S1857.

Vogel, A.I. (1989). "Vogel's Textbook of Quantitative Analysis". $5^{\text {th }}$ ed., Longoman Scientific and Technical, England, pp. 324-329, 349.

Zareef, M.; Iqbal, R.; Zaidi, J.H.; Qadeer, G.; Wong, W.Y.; Akhtar, H. (2006). Crystal structure of picolinic acid hydrazide, $\mathrm{C}_{6} \mathrm{H}_{7} \mathrm{~N}_{3} \mathrm{O}$. Z. Kristallogr. NCS, 221, 307-308. 